\title{
Examining the Effect of Social-Emotional Prevention Program on Social and Communication Skills of Disadvantaged Preschool Children ${ }^{1}$
}

\author{
Hülya GÜLAY OGELMAN
}

Hatice ERTEN SARIKAYA

Ministry of Education

Hande GÜNGÖR

Pamukkale University

Özlem KÖRÜKÇÜ

Pamukkale University

\begin{abstract}
The purpose of the project was to investigate the effect of the Social-Emotional Prevention Program on social and communication skills of 4-6 year-old children attending preschool education and having families with low socio-economic level. In the study, quasi-experimental design with pretest-posttest group was used. Three experimental groups and one control group were included in the project. Average age of the children in all the groups was 5 years, 1 month, and 27 days (minimum 4 years, 1 month, and 16 days; maximum 6 years and 3 days). 83 children and 83 mothers including 25 children and 25 mothers in the age group of 4-6 years from Experimental Group 1, 16 children and 16 mothers from Experimental Group 2, 16 children and 16 mothers from Experimental Group 3, and 26 children and 26 mothers from Control Group were included in the project. All of 83 children involved in the all groups were attending independent kindergartens affiliated with Ministry of National Education, Provincial Directorate for National Education of Denizli in Pamukkale and Tavas districts of Denizli. Personal Information Form, Social Skills Evaluation Scale (SSES), and Communication Skills Scale (Teacher Form) were used as the data collection tools in the project. According to the results of the study, implementing Social-Emotional Prevention Program together with family involvement activities, implementing only Social-Emotional Prevention Program, and implementing only family involvement activities led to significant improvements in the social and communication skills of the children compared to the control group.
\end{abstract} Submitted 10.02.2019 Revised 04.2019

\section{Suggested Citation:}

Gülay-Ogelman, H., Erten-Sarıkaya, H., Güngör, H., \& Körükçü, Ö. (2018). Examining the Effect of Social-Emotional Prevention Program on Social and Communication Skills of Disadvantaged Preschool Children, International Journal of Academic Research in Education, 4(1-2), 27-40. DOI: 10.17985/ijare.525173

\footnotetext{
${ }^{1}$ This study was supported with the number: 2015HZL024 within Short-Term Project Groupby Pamukkale University in the 2015-2016 academic year.
} 


\section{INTRODUCTION}

Social and emotional skills are important skills that are required to be supported in the preschool period. Fundamental emotional skills in the preschool period are recognition of emotions, understanding of emotions, expression of emotions, and regulation of emotions. On the other hand, social skills are skills that assist in establishing healthy relationships with other people such as obeying the rules, establishing positive relationships, taking responsibilities, being sensitive towards others, and controlling negative emotions. Emotional skills are associated with social skills. In other words, children, who are social beings in the society and have less behavioral problems, are the children with high level of emotional skills (Ramazan and Ünsal, 2012; Saltalı, 2013).

Social and emotional incompetence is more widespread in children raised in risky environmental settings including divorced parents, starvation, homelessness, neglect, hostile or inconsistent parental practices, and parents' psychological problems. In the literature, the prevalence of severe emotional/behavioral problems in children varies between $5 \%$ and $26 \%$ (Brauner and Stephens, 2006). Problems associated with social and emotional incompetence may cause academic problems, dropping out school, substance abuse, crime, and violence in the following years (Tremblay, Pagani-Kurtz, Mâsse, Vitaro and Pihl, 1995).

Three types of applications are performed for children suffering from behavioral problems due to social and emotional incompetence: social skill training, the use of behavioral enhancement for increasing the adjustment, and parental training. Social skill training is a program developed for children with deficiency of social skills and peer relationship problems due to internalization and externalization problems. Behavioral enhancement is a game-like technique which firstly starts with principle requests for children who do not obey the rules and requests and describes desired behavior after three or four requests. Parental training programs are the programs that enhance the competence levels of parents (Merrell, 1996).

The need for programs aiming at enhancing emotional and social skills of individuals and decreasing violence and aggression has increased especially during last decade. The studies have reported an increase in number of negative behaviours such as aggression and bullying in the schools. Due to various reasons, children can have deficiencies in skills such as sharing, waiting their turn, listening, showing empathy, showing tolerance, cooperating, expressing their emotions properly, and coping with failure. Therefore, it is crucial to develop programs that will enable children to develop successful peer relations at early ages and support them to be socially and emotionally compatible and happy individuals. A number of studies have revealed that social and emotional learning lying behind such programs enables children to acquire emotional and social skills at early ages such as anger management, emotional regulation, expressing emotions properly, empathising, showing tolerance, sharing, helping each other, playing together, adjusting, cooperating, using words of courtesy, solving their social problems unaggressively, and protecting their friends (Elias, Parker, Kash, Weissberg, \& O’Brien, 2008; Kam, Greenberg, \& Kusche, 2004).

Many programs have been developed abroad for children with social and emotional incompetence in the preschool period and they include Fun Friends, PATHS (Promoting Alternative Thinking Strategies), Strong Start, and Incredible Years. Being developed for enhancing social-emotional competences of children and decreasing their emotional-behavioral problems, these programs are comprehensive programs that include the involvements of children, family, and teacher. In Turkey, researchers also develop programs to improve the social skills of preschool children (Alp, 2016; Aslan, 2008; Ekinci-Vural, 2006; Göktaş, 2015; Özdemir-Topaloğlu, 2013; Polat and Dilli, 2015; Uysal and Kaya-Balkan, 2015). In addition to these programs that include involvements of children and parents, other programs covering only the parental training are present, as well (Sayın, 2014). 
In recent years, behavior patterns that may harm social and school adjustment of preschool children such as aggression and peer violence have increased. This increase is associated with several problems, in which families can be directly effective, such as changing family structure, various familial problems, and negative parental attitudes. In response to this change and increasing problematic behaviours, it is important to develop intervention program for children in the preschool period, when significant foundations are laid in the life, and their parents, to increase projects, and follow up longitudinally applications in terms of developing countries such as Turkey in particular (Göktaş, 2015; Gülay Ogelman, 2017).

In the present study, the Social-Emotional Prevention program developed by Stefan (2012) was used. The Social Emotional Prevention Program (SEP) is a versatile early prevention program. The program developed in Romania aims to increase the social and emotional competence of preschool children. Family involvement is also included in the program. The purpose of family involvement is to inform parents about their children's social and emotional development and to provide to develop positive disciplinary strategies. The program has been developed for children of disadvantaged families (low income level, multi-children, migration, divorce, maternal depression, etc.) (Stefan, 2012). SEP was developed as a community-based intervention in line with recommended prevention strategies emphasizing the implementation of such programs to larger group of children (Conroy, Stichter, Daunic, \& Haydon, 2008. Cited by: Stefan,2012, p.321). The underlying assumption is that majority of the children, who could benefit mostly from participating into prevention programs in the preschools, do not show patterns of clinical level symptoms, but they might be at risk in the future if they continue to display these behaviours (Stefan,2012, p.321).

\section{The aim of the study}

The program was preferred since it was developed especially for the purpose of preventing the socialemotional incompetence. The aim of this study was to examine the effect of Social-Emotional Prevention Program on social and communication skills of 4-6 year-old children, who attended preschool education and had families with low socio-economic level. In accordance with this purpose, the research questions are as follows:

1. Does the Social-Emotional Prevention Program applied both in the school and at home have a significant effect on social skills of 4-6 year-old children in the experimental group 1?

2. Does the Social-Emotional Prevention Program applied both in the school and at home have a significant effect on communication skills of 4-6 year-old children in the experimental group 1?

3. Does the Social-Emotional Prevention Program applied only in the school have a significant effect on social skills of 4-6 year-old children in the experimental group 2 ?

4. Does the Social-Emotional Prevention Program applied only in the school have a significant effect on communication skills of 4-6 year-old children in the experimental group 2 ?

5. Does the family involvement activities applied only at home have a significant effect on social skills of 4-6 year-old children in the experimental group 3?

6. Does the family involvement activities applied only at home have a significant effect on communication skills of 4-6 year-old children in the experimental group 3 ?

\section{METHOD}

In the project conducted on implementation of Social Emotional Prevention Program among 4-6 year-old children, the quasi-experimental design with pretest-posttest group was used as the study method. The random design with pretest and posttest control group is one of the most frequently used experimental designs in the education and psychology. Experimental design is defined as research designs used for finding out the cause and effect relationships between variables (Büyüköztürk, 2007). On the other hand, the aim of quasi-experimental design is also the same as experimental design. The difference between them is that control and experimental groups are selected with measurements instead of random selection in the quasi-experimental design (Ekiz, 2003; Karasar, 2006). There are three experimental groups and one control group within the scope of the project. 


\section{Study Groups}

The schools, where the study was conducted, were selected by using convenience sampling in order for the study to accelerate and gain practicability (Yıldırım \& Şimşek, 2006). Necessary permissions were obtained from Ministry of National Education, Provincial Directorate for National Education of Denizli. There were three experimental groups and one control group in the project. All of 83 children in all the groups attended independent kindergartens affiliated with Provincial Directorate for National Education of Denizli under Ministry of Education in Pamukkale and Tavas districts of Denizli city. The average age of the children was 5 years, 1 month, and 27 days (minimum 4 years, 1 month and 16 days, and maximum 6 years and 3 days).

The experimental group 1 included 25 children in the age group of 4 and 6 years and 25 mothers. The experimental group 2 included 16 children and 16 mothers. The experimental group 3 included 16 children and 16 mothers and the control group included 26 children and 26 mothers. A total of 83 children and 83 mothers were included in the project. The children who were residing in Pamukkale, Merkezefendi and Tavas districts, had families with low socio-economic level, and were disadvantaged due to various reasons were determined by visiting schools. Two independent kindergartens were detected in Pamukkale and Tavas districts as a result of the interviews made with the administrators and teachers.

According to the study groups, the conditions creating disadvantages for the children can be summarized as follows: the father of one of 25 children in the experimental group 1 was receiving psychological treatment and there was domestic violence. One of the children was born prematurely and domestic violence was observed in that child's home. One of the children had an extended family in which three generations were all living together. Parents of two children got divorced and these children were living with their mothers. A child had introversion as in parents and the family members were very quiet and could not interact with their environment.

One of 16 children in the experimental group 2 was one of premature triplet siblings and another child was one of twin siblings with speech problems. Parents of three children in the same group got divorced and these children were living with their mothers. One of the children had the father in prison and one other child had behavioral disorders of stuttering and nail biting. Three children had an extended family, in which three generations were living together, with many siblings.

Parents of one of 16 children in the experimental group 3 got divorced, three children had their mother and father living separately, and fathers of two children were committing violence to their mothers.

Parents of three of 26 children in the control group got divorced, fathers of three children were committing violence to the mother, and two children had an extended family. The teachers stated that all of these disadvantaged children in the study groups had common problems such as aggression, failing to obey instructions, oppressive behavior towards their peers, not participating in games, and lack of school adjustment. The children in the experimental group 1 were subjected to Social Emotional Prevention Program in the school and family involvement activities at home. Those the experimental group 2 were subjected to only the Social Emotional Prevention Program in the school and no family involvement activities were carried out at home. In the experimental group 3, family involvement activities were applied at home, but the Social Emotional Prevention Program was not applied at school. In the control group, no program was applied in the school and at home.

The distribution of the study groups based on sex was as follows: the experimental group 1 included 8 girls (32.0\%) and 17 boys (68.0\%); the experimental group 2 included 10 girls (62.5\%) and 6 boys (37.5\%); the experimental group 3 included 7 girls (43.8\%) and 9 boys (56.3\%); and control group included 14 girls (53.8\%) and 12 boys (46.2\%).

The distribution of the mothers in terms of their educational level was as follows: $5(20.0 \%)$ of the mothers in the experimental group 1 were primary school graduate, 16 (64.0\%) were secondary school graduate, and 4 (16.0\%) were high school graduate. Eight $(50.0 \%)$ of the mothers in the experimental group 2 were primary school graduate, 7 (43.8\%) were secondary school graduate, and $1(6.3 \%)$ was high school graduate. One (6.3\%) of the mothers in the experimental group 3 was illiterate, 9 (56.3\%) were primary school graduate, 3 (18.8\%) were secondary school graduate, 2 (12.5\%) were high school graduate, and $1(6.3 \%)$ had a bachelor's degree. Two $(7.7 \%)$ of the mothers in the control group were illiterate, 15 (57.7\%) primary school graduate, 4 (15.4\%) were secondary school graduate, 4 (15.4\%) were high school graduate, and 1 (3.8\%) had a bachelor's degree.

The distribution of the fathers in terms of their educational level was as follows: 2 (8.0\%) of the fathers in the experimental group 1 were primary school graduate, 5 (20.0\%) were secondary school graduate, and $18(72.0 \%)$ were high school graduate. Six (37.5\%) of the fathers in the experimental group 2 were primary school graduate, $3(18.8 \%)$ were secondary school graduate, and 7 (43.8\%) were high school 
graduate. Two (12.5\%) of the fathers in the experimental group 3 were literate, 5 (31.3\%) were primary school graduate, 3 (18.8\%) were secondary school graduate, 4 (25.0\%) were high school graduate, and 2 (12.5\%) had a bachelor's degree. One (3.8\%) of the fathers in the control group was literate, $18(69.2 \%)$ primary school graduate, 1 (3.8\%) were secondary school graduate, and 6 (23.1\%) were high school graduate.

The distribution of the mothers in terms of their age groups was as follows: $5(20.0 \%)$ of the mothers in the experimental group 1 were aged between 20-30 years, 16 (64.0\%) were aged between 31-40 years, and $4(16.0 \%)$ were in the age group of 41 years and over. $8(50.0 \%)$ of the mothers in the experimental group 2 were aged between $20-30$ years and 8 (50.0\%) were aged between $31-40$ years. $8(50.0 \%)$ of the mothers in the experimental group 3 were aged between $20-30$ years and $8(50.0 \%)$ were aged between $31-40$ years. $3(11.5 \%)$ of the mothers in the control group were aged between $20-30$ years, 21 (80.8\%) were aged between $31-40$ years, and 2 (7.7\%) were in the age group of 41 years and over.

The distribution of the fathers in terms of their age groups was as follows: $3(12.0 \%)$ of the fathers in the experimental group 1 were aged between 20-30 years, 18 (72.0\%) were aged between 31-40 years, and $4(16.0 \%)$ were in the age group of 41 years and over. Five (31.3\%) of the fathers in the experimental group 2 were aged between 20-30 years and 11 (68.8\%) were aged between 31-40 years. One (6.3\%) of the fathers in the experimental group 3 was aged between 20-30 years, 12 (75.0\%) were aged between $31-40$ years, and $3(16.8 \%)$ were in the age group of 41 years and over. Three $(11.5 \%)$ of the fathers in the control group were aged between $20-30$ years, 17 (65.4\%) were aged between 31-40 years, and 6 (23.1\%) were in the age group of 41 years and over.

The distribution of the mothers in terms of their employment status was as follows: Twenty three (92.0\%) of the mothers in the experimental group 1 were housewife and 2 (8.0\%) were self-employed. Twelve (75.0\%) of the mothers in the experimental group 2 were housewife and 4 (25.0\%) were worker. Thirteen (81.3\%) of the mothers in the experimental group 3 were housewife and 3 (18.8\%) were worker. Sixteen (61.5\%) of the mothers in the control group were housewife and 10 (38.5\%) were worker.

The distribution of the fathers in terms of their employment status was as follows: Four (16.0\%) of the fathers in the experimental group 1 were worker, $5(20.0 \%)$ were civil servant, $15(60.0 \%)$ were selfemployed, and 1 (4.0\%) was retired. 12 (75.0\%) of the fathers in the experimental group 2 were worker, 2 (12.5\%) were self-employed, 1 (6.3\%) was unemployed, and 1 (6.3\%) was civil servant. Nine (56.3\%) of the fathers in the experimental group 3 were worker, 2 (12.5\%) civil servant, and $5(31.3 \%)$ were selfemployed. One (3.8\%) of the fathers in the control group was unemployed, 12 (46.2\%) were worker, 3 (11.5\%) were civil servant, and 10 (38.5\%) were self-employed.

The distribution of the study groups in terms of number of sibling was as follows: Six (24.0\%) children in the experimental group 1 had no sibling, 14 (56.0\%) had one sibling, 4 (16.0\%) had two siblings, and 1 (4.0\%) had three or more siblings. Three (18.8\%) children in the experimental group 2 had no sibling, 8 children (50.0\%) had one sibling, 4 (25.0\%) had two siblings, and 1 (6.3\%) had three or more siblings. Three (18.8\%) children in the experimental group 3 had no sibling, 7 (43.8\%) had one sibling, 3 (18.8\%) had two siblings, and $3(18.8 \%)$ had three or more siblings. In the control group 7 children (26.9\%) had no sibling, 9 (34.6\%) had one sibling, 7 (26.9\%) had two siblings, and $3(11.5 \%)$ had three or more siblings .

\section{Data Collection Tools}

"Personal Information Form, Social Skills Evaluation Scale (SSES), and Communication Skills Scale (Teacher Form)" were used as the measurement tools in the project. The Personal Information Form was prepared by the researchers. The form involved information of the children in the experimental and control groups about gender, age, date of birth, birth order, educational status of parents, profession of parents, and siblings.

Social Skills Evaluation Scale (SSES): It was developed by Avcıoğlu (2007) and its validity and reliability study was conducted. Social Skills Evaluation Scale prepared for measuring the social skills of 4-6 year-old children has 62 items in the five-point Likert type (always (5), often (4), usually (3), slightly (2), and never (1)). Social Skills Evaluation Scale measures nine domains. These domains are stated below:

1. Interpersonal Skills (IS): It is the subscale of interpersonal skills which are important for maintaining interpersonal mutual interaction. It consists of 15 items.

2. Anger Management and Accommodation Skills (AMAS): They refer to the skills assisting individuals for controlling their own and others' anger behaviours in social interaction, as well as providing their easily accommodation to changes. It includes 11 items. 
3. Coping with Peer Pressure Skills (CWPPS): They refer to the skills assisting individuals for coping with various peer pressures in social interaction. It includes 10 items.

4. Self-Control Skills (SS): They refer to the skills assisting individuals for controlling themselves over their social behaviors. This subscale includes 4 items.

5. Verbal Explanation Skills (VES): They refer to the skills starting and maintaining interactions between the individuals. The subscale of Verbal Explanation skills includes 7 items.

6. Outcome Accepting Skills (OAS): They refer to the skills assisting individuals for accepting various possible outcomes. This subscale includes 4 items.

7. Listening Skills (LS): They refer to the skills starting and maintaining the interaction between the individuals. Listening skills includes 5 items.

8. Purpose Forming Skills (PFS): It is the subscale of the skills providing individuals to form purposes independently from others and also to achieve these purposes. The subscale of Purpose Forming Skills includes 3 items.

9. Task Completing Skills (TCS): They refer to the skills assisting individuals for fulfilling their tasks. This subscale includes 3 items.

The overall scale consists of positive items. In its validity and reliability study, Avcıoğlu (2007) found the test-retest coefficient as $r=.83$ for the overall scale and between .60 and .98 for the subscales (.98 for Interpersonal Skills, .73 for Anger Management and Accommodation Skills, .82 for Coping with Peer Pressure Skills, .78 for Self-Control Skills, .83 for Verbal Explanation Skills, .73 for Outcome Accepting Skills, .90 for Listening Skills, .79 for Purpose Forming Skills, and .60 for Task Completing Skills). While the internal consistency (Cronbach's alpha) coefficient was found as .98 for the overall scale and as .78 and .95 for the subscales (.95 for Interpersonal Skills, .94 for Anger Management and Accommodation Skills, .92 for Coping with Peer Pressure Skills, .91 for Self-Control Skills, .85 for Verbal Explanation Skills, .95 for Outcome Accepting Skills, .87 for Listening Skills, .78 for Purpose Forming Skills, and .88 for Task Completing Skills).

Communication Skills Scale (Teacher Form): It was developed by Önder, Dağal and Şallı (2015). The scale consists of 46 items and four subscales. The subscales of the scale are having active communication, taking into account the value of communication, following the rules of communication, and positive response demonstration. The internal consistency value (Cronbach's alpha value) of the subscales was determined as 0.979 for the subscale of "having active communication"; 0.974 for the subscale of "taking into account the value of communication"; 0.970 for the subscale of "following the rules of communication "; and 0.870 for the subscale of "positive response demonstration". The total score obtained the scale and its subscales is interpreted as highness of the level of communication skills of children (Önder, Dağal and Şallı, 2015).

\section{Application}

Social Emotional Prevention Program: The Social Emotional Prevention Program (SEP) is a multifocused early prevention program developed by Stefan (2012) in Romania for children of families with disadvantages. Aiming to increase social and emotional competences of preschool children, the program also includes family involvement. The curriculum for children's emotional and social development included teacher-implemented classroom activities. Activities were included in five modules aiming: 1) the development of children's emotional competences (emotion recognition and emotion regulation); and 2) the development of social competences (compliance to rules, problem-solving, and prosocial behaviors such as turn-taking, toy sharing, and cooperating during group play activities). In each module, there are various types of activities (games, drama, language activities, etc.). The sixteen-week program lasts for 39 days.

The application of the project is mentioned below in general terms:

1. The study groups were determined in accordance with the permission of Ministry of National Education.

2. Pretests were applied to the mothers and children in the experimental group 1, experimental group 2 and control group.

3. The teachers and mothers in the experimental group 1 and undergraduate students participating in the applications were trained about the project and its subject.

4. The teachers in the experimental group 2 were trained about the project and its subject.

5. The training program was applied.

6. Posttests were applied to the mothers and children in the experimental group 1, experimental group

2, and control group.

The application of the project for each group was explained below in details: 
The Application in the Experimental group 1: The program was applied both in the class and also family involvement activities were performed at home in the experimental group 1. A 5-day training on emotional development in preschool period, social problem solving in preschool period, and the introduction of Social Emotional Prevention Program was provided to the preschool teachers in this experimental group. The training had a detailed content in accordance with the program (purpose, application, materials, essential points, etc.) and the subjects under its scope (emotional development and social problem solving). Moreover, the mothers of children in this group were provided with a oneday seminar including family involvement activities. In the experimental group 1, the trained teachers applied the program in their own class. Throughout their applications, the project team coordinator, four researchers, and two four-year students of Pamukkale University Preschool Education Department guided the preschool teachers of the experimental group 1.

The Application in the Experimental group 2: In the experimental group 2, the program was only applied in the class and no family involvement activity was implemented. A 5-day training on emotional development in preschool period, social problem solving in preschool period, and the introduction of Social Emotional Prevention Program was provided to the preschool teacher in this experimental group. No training was provided for the mothers. In the experimental group 2, the trained teachers applied the program in their own class. Throughout their applications (as in experimental group 1), the project team coordinator, four researchers, and two four-year students of Pamukkale University Preschool Education Department guided the preschool teachers in this group. The two undergraduate students to make voluntary contribution in the project received the same training as two preschool teachers in the second experimental group. The aim in the experimental group 2 was to reveal whether the activities at the school had an effect in the emotional and social competences or not.

The Application in the Experimental group 3: In the experimental group 3, only the family involvement activities were implemented and no activity was applied in the school. Only a training on family involvement was provided with the teacher in this experimental group. The aim in the experimental group 3 was to reveal whether family involvement activities had an effect on emotional and social competences of the children or not. As the family involvement activity, 22 family involvement activities, which could be implemented by the children together with their mothers at home and were parallel to activities in the school, were prepared.

The Application in the Control Group: The teachers and mothers in the control group was not informed in any way. No program was applied to the children and the mothers.

The implementation of the project began on 15 February and were completed on 18 June 2016. The preschool teachers filled in Personal Information Form, Social Skills Evaluation Scale (SSES), and Communication Skills Scale (Teacher Form) for each child.

Data Analysis

The data were analyzed by using SPSS 18.0 packaged software. Since the number of children and mothers remained below 30 in all of the groups, non-parametrical tests were used for the analysis. To compare the scores of the four study groups, Kruskal Wallis $\mathrm{H}$ test was used for the unrelated samples; and Wilcoxon Signed Rank Test for the related measurements was used for intra-group comparison of the pretest and posttest measurements of the study groups. 


\section{RESULTS}

Table 1.

Results of Kruskal Wallis Test for Pretest Measurements of Social Skill Scores based on Experimental and Control Groups

Pretest Measurements for Social Skill Levels

\begin{tabular}{|c|c|c|c|c|c|c|}
\hline Study groups & $\mathrm{n}$ & Mean rank & $\mathrm{sd}$ & $x^{2}$ & $p$ & $\begin{array}{l}\text { Significant } \\
\text { difference }\end{array}$ \\
\hline $\begin{array}{l}\text { Experimental } \\
\text { group } 1\end{array}$ & 25 & 36.18 & 3 & 2.565 & .464 & - \\
\hline $\begin{array}{l}\text { Experimental } \\
\text { group } 2\end{array}$ & 16 & 41.59 & & & & \\
\hline $\begin{array}{l}\text { Experimental } \\
\text { group } 3\end{array}$ & 16 & 43.75 & & & & \\
\hline Control & 26 & 46.77 & & & & \\
\hline
\end{tabular}

Posttest Measurements for Social Skills Levels

\begin{tabular}{|c|c|c|c|c|c|c|}
\hline Study groups & $\mathrm{n}$ & Mean rank & $\mathrm{sd}$ & $x^{2}$ & $p$ & $\begin{array}{l}\text { Significant } \\
\text { difference }\end{array}$ \\
\hline $\begin{array}{l}\text { Experimental } \\
\text { group } 1\end{array}$ & 25 & 61.44 & 3 & 20.615 & $.000^{*}$ & $\begin{array}{l}\text { D1-K, D2-K, } \\
\text { D3-K, D1-D2, }\end{array}$ \\
\hline $\begin{array}{l}\text { Experimental } \\
\text { group } 2\end{array}$ & 16 & 46.25 & & & & D1-D3, D2-D3 \\
\hline $\begin{array}{l}\text { Experimental } \\
\text { group } 3\end{array}$ & 16 & 42.12 & & & & \\
\hline Control & 26 & 27.31 & & & & \\
\hline
\end{tabular}

According to Table 1, no significant difference was found among the pretest mean scores of experimental and control groups for their social skills $\left(X^{2}{ }_{(3)}=2.565, p>.05\right)$. On the other hand, there was a significant difference among the posttest measurements of the groups for their social skills. In addition to the significant difference among all the experimental groups and control group in favor of the experimental groups; a significant difference was determined among the experimental groups $\left(X^{2}(3)=20.615, p<.01\right)$. In the posttest measurements, the highest mean rank in terms of social skills was observed in the experimental group 1, which was followed by the experimental group 2, the experimental group 3, and the control group, respectively. 
Table 2.

Results of Kruskal Wallis Test for Pretest Measurements of Communication Skill Scores

\begin{tabular}{lcccccc}
\hline \multicolumn{2}{l}{ Pretest Measurements for Communication Skill Levels } & & & \\
\hline Study groups & $\mathrm{n}$ & $\begin{array}{l}\text { Mean } \\
\text { Rank }\end{array}$ & sd & $\mathrm{X}^{2}$ & $\mathrm{p}$ & $\begin{array}{c}\text { Significant } \\
\text { difference }\end{array}$ \\
\hline $\begin{array}{l}\text { Experimental } \\
\text { group 1 }\end{array}$ & 25 & 42.62 & 3 & 1.041 & .791 & - \\
\hline $\begin{array}{l}\text { Experimental } \\
\text { group 2 }\end{array}$ & 16 & 39.38 & & & & \\
\hline $\begin{array}{l}\text { Experimental } \\
\text { group 3 }\end{array}$ & 16 & 38.38 & & & \\
\hline Control & 26 & 42.25 & & & \\
\hline
\end{tabular}

Posttest Measurements for Communication Skill Levels

\begin{tabular}{|c|c|c|c|c|c|c|}
\hline Study groups & $\mathrm{n}$ & $\begin{array}{l}\text { Mean } \\
\text { Rank }\end{array}$ & $\mathrm{sd}$ & $x^{2}$ & $p$ & $\begin{array}{l}\text { Significant } \\
\text { difference }\end{array}$ \\
\hline $\begin{array}{l}\text { Experimental } \\
\text { group } 1\end{array}$ & 25 & 59.88 & \multirow[t]{4}{*}{3} & \multirow[t]{4}{*}{18.608} & \multirow[t]{4}{*}{$.000^{*}$} & \multirow{4}{*}{$\begin{array}{l}\text { D1-K, D2-K, } \\
\text { D3-K, D1-D2, } \\
\text { D1-D3, D2-D3 }\end{array}$} \\
\hline $\begin{array}{l}\text { Experimental } \\
\text { group } 2\end{array}$ & 16 & 48.20 & & & & \\
\hline $\begin{array}{l}\text { Experimental } \\
\text { group } 3\end{array}$ & 16 & 33.19 & & & & \\
\hline Control & 26 & 30.19 & & & & \\
\hline
\end{tabular}

$\mathrm{p}<.01$

In Table 2, no significant difference was found among the pretest mean scores of experimental and control groups for their communication skills $\left(X^{2}{ }_{(3)}=1.041, p>.05\right)$. On the other hand, in the posttest measurements related to the communication skills, there was a significant difference among the groups. In addition to the significant difference among all the experimental groups and control group in favor of the experimental groups; a significant difference was determined among the experimental $\operatorname{groups}\left(X^{2}(3)=18.608, p<.01\right)$. In the posttest measurements, the highest mean rank in terms of communication skills was observed in the experimental group 1 , which was followed by the experimental group 2, the experimental group 3, and the control group, respectively.

Table 3.

Results of Wilcoxon Signed Rank Test for Social and Communication Skill scores of the Experimental group 1

\begin{tabular}{|c|c|c|c|c|c|}
\hline & \multicolumn{5}{|c|}{ Social Skill Levels } \\
\hline $\begin{array}{l}\text { Posttest- } \\
\text { Pretest }\end{array}$ & $\mathrm{n}$ & $\begin{array}{l}\text { Mean } \\
\text { Rank }\end{array}$ & Total Rank & $z$ & $p$ \\
\hline Negative rank & 5 & 5.80 & 29.00 & 3.59 & $.000 *$ \\
\hline Positive rank & 20 & 14.80 & 296.00 & & \\
\hline \multirow[t]{2}{*}{ Equal } & 0 & & & & \\
\hline & Cor & Skill Le & & & \\
\hline $\begin{array}{l}\text { Posttest- } \\
\text { Pretest }\end{array}$ & $\mathrm{n}$ & $\begin{array}{l}\text { Mean } \\
\text { Rank }\end{array}$ & Total Rank & $z$ & $\mathrm{p}$ \\
\hline Negative rank & 9 & 9.22 & 83.00 & 2.14 & $.032 * *$ \\
\hline Positive rank & 16 & 15.13 & 242.00 & & \\
\hline Equal & 0 & & & & \\
\hline
\end{tabular}

In Table 3, it was found that there was a significant difference between pretest and posttest scores of the experimental group 1 before and after the program as a result of the measurements made for social skills $(z=3.59 ; p<.01)$ and communication skills $(z=2.14 ; p<.05)$. 
Table 4.

Results of Wilcoxon Signed Rank Test for Social and Communication Skill scores of the Experimental group 2

\begin{tabular}{llllll}
\hline \multicolumn{7}{l}{ Social Skill Levels } & & \\
\hline Posttest- Pretest & $\mathrm{n}$ & Mean Rank & Total Rank & $\mathrm{z}$ & $\mathrm{p}$ \\
\hline Negative rank & 2 & 9.00 & 18.00 & 2.59 & $.010^{*}$ \\
\hline Positive rank & 14 & 8.43 & 118.00 & & \\
\hline Equal & 0 & & & \\
\hline \multicolumn{7}{l}{ Communication Skill Levels } & & \\
\hline Posttest- Pretest & $\mathrm{n}$ & Mean Rank & Total Rank & $\mathrm{z}$ & $.003^{*}$ \\
\hline Negative rank & 3 & 3.33 & 10.00 & 3.00 & \\
\hline Positive rank & 13 & 9.69 & 126.00 & & \\
\hline Equal & 0 & & &
\end{tabular}

In Table 4, it was found that there was a significant difference between pretest and posttest scores of the experimental group 2 before and after the program as a result of the measurements made for social skills $(z=2.59 ; p<.05)$ and communication skills $(z=3.00 ; p<.05)$.

Table 5.

Results of Wilcoxon Signed Rank Test for Social and Communication Skill scores of the Experimental group 3

\begin{tabular}{|c|c|c|c|c|c|}
\hline & \multicolumn{5}{|c|}{ Social Skill Levels } \\
\hline Posttest- Pretest & $\mathrm{n}$ & Mean Rank & Total Rank & $z$ & $p$ \\
\hline Negative rank & 2 & 11.00 & 22.00 & 2.16 & $.031^{*}$ \\
\hline Positive rank & 13 & 7.54 & 98.00 & & \\
\hline \multirow[t]{2}{*}{ Equal } & 1 & & & & \\
\hline & Cor & Skill Levels & & & \\
\hline Posttest- Pretest & $\mathrm{n}$ & Mean Rank & Total Rank & $z$ & $p$ \\
\hline Negative rank & 5 & 9.80 & 49.00 & .62 & .532 \\
\hline Positive rank & 10 & 7.10 & 71.00 & & \\
\hline Equal & 1 & & & & \\
\hline
\end{tabular}

$* \mathrm{p}<.05$

In Table 5, it was found that there was a significant difference between pretest and posttest scores of the experimental group 3 before and after the program as a result of the measurements made for social skills $(z=2.16 ; p<.05)$. In the same table, it was observed that there was no significant difference between pretest and posttest measurements in terms of the variable of communication skills $(z=.62 ; p>.05)$.

Table 6.

Results of Wilcoxon Signed Rank Test for Social and Communication Skill scores of Control Group

\begin{tabular}{llllll}
\hline \multicolumn{7}{c}{ Social Skill Levels } & & \\
\hline Posttest- Pretest & $\mathrm{n}$ & Mean Rank & Total Rank & $\mathrm{z}$ & $\mathrm{p}$ \\
\hline Negative rank & 12 & 13.21 & 158.50 & 1.99 & $.046^{*}$ \\
\hline Positive rank & 8 & 6.44 & 51.50 & & \\
\hline Equal & 6 & & & \\
\hline \multicolumn{7}{c}{ Communication Skill Levels } & & $\mathrm{p}$ \\
\hline Posttest- Pretest & $\mathrm{n}$ & Mean Rank & Total Rank & $\mathrm{z}$ & .104 \\
\hline Negative rank & 16 & 14.97 & 239.50 & 1.63 & \\
\hline Positive rank & 10 & 11.15 & 111.50 & & \\
\hline Equal & 0 & & &
\end{tabular}

In Table 6, it was found that there was a significant difference between pretest and posttest scores of the control group before and after the program as a result of the measurements made for social skills ( $z=$ 1.99; $p<.05)$. In the same table, it was observed that there was no significant difference between pretest and posttest measurements in terms of the variable of communication skills $(z=1.63 ; p>.05)$. 


\section{DISCUSSION \& CONCLUSION}

In this study, examining the effect of Social-Emotional Prevention Program on social and communication skills of 4-6 year-old children, who attended preschool education and had families with low socioeconomic level, the applications made to the children in the experimental groups led significant improvements in their social and communication skills compared to the control group. In the study conducted by the program developer Stefan (2012) in Romania, significant improvements were observed in social competence. The programs carried out abroad such as Fun Friends, PATHS, Strong Start and Incredible Years have led to significant improvements in social competences and social interactions of the children (Domitrovich, Cortes and Greenberg, 2007; Kramer, Caldarella, Christensen and Shatzer, 2010; Pahl and Barrett, 2007; Webster-Stratton and Reid, 2004). In a study conducted with the disadvantaged 101 immigrant families and their children in the age group of 3-5 years, who did not attend the preschool education, in Australia, the families were informed about the family involvement activities such as home visits, group meetings and many other matters especially child education. Their questions were answered with one-to-one interviews. At the end of the program, there was an increase in the rate of starting the preschool education in children and the day time the families spent with their children (Grace, Boews \& Elcombe, 2014). In the United States of America, six disadvantaged 6 year-old children (of migrated multichild low-income families) attended a kindergarten, where Head Start Program was applied, with their parents for one year. At the end of one-year preschool education, it was revealed that significant improvements were observed in children's social competences (Clay, 1995).

Families are more involved in the education process through their family involvement studies and they can monitor the development of their children more consciously. During this process, parents can spend more time with their children, produce more strategies about their education and have an increased motivation for education (Eccles \& Harold, 1993). In a study conducted with 53 families in Thailand (Tulunanda, 1999), it was determined that the increase in quality time parents spent with their children affected positively mother-father-child relationships, decreased disciplinary problems, and had a positive effect on social skills of children in the school.

The programs prepared by Turkish researchers have increased social skills of children (Alp, 2016; Aslan, 2008; Ekinci Vural, 2006; Göktaş, 2015; Özdemir Topaloğlu, 2013; Polat and Dilli, 2015; Uysal and Kaya Balkan, 2015). This has suggested that the programs developed for children with social-emotional incompetence are useful for increasing social competences and communication skills of children.

Additionally, the most effective one among all the applications was the social-emotional prevention program and family involvement activities applied to children. The second important improvement was observed in the children for whom only social-emotional prevention program was applied, and the third one was observed in the group where only family involvement was applied. As a model to their children, parents play an important role in their social-emotional development through their interactions with their children (Kandır and Alpan, 2008). Therefore, family involvement is significant in increasing the parental competences. In fact, in the Social Skills Education program applied by Göktaş (2015) to improve the social skills of 4-5 year-old children, the greatest improvement was observed in the application of family involvement program; on the other hand, the second major improvement was determined in the children for whom only the program was applied, and the third one was observed in the group where only family involvement was applied. As is seen, family involvement affected the effect of the program applied to the children. Besides, family involvement programs have a long-lasting effect (Webster-Stratton and Hammond, 1997).

A significant result of the study revealed that even the family involvement alone could lead to an increase in social and communication skills of the children. Training programs applied by Sayın (2014) and Yalçın (2013) to the mothers with preschool children increased the social competence of the children and also 
decreased the family communication problems. This result supports the result indicating that motherchildren relationships and the family stress are an indicator for the social-emotional competence of the child (Schmidt, Demulder and Denham, 2002). Such programs should be also included in undergraduate programs of preschool teaching and child development. The fact that $46 \%$ of the preschool teachers do not have sufficient knowledge about behavioral problems (Yumuş, 2013) and the university instructors have stated they give less education on this matter shows the importance of this situation (Hemmeter, Santos and Ostrosky, 2008).

In this study, no application was carried out in the control group; however, an increase was observed in their social skill scores. This can be associated with the effect of preschool education. Preschool education programs are programs prepared for developing social and emotional skills of children along with their cognitive, motor, self-care, and language skills. Therefore, the increase observed in the social skills of the control group was associated with the effect of preschool education.

Some suggestions can be made for the future studies in line with the limitations of this study. In this study, the Social Emotional Prevention Program developed by Stefan (2012) was used. This program and the other programs applied abroad can be compared in terms of their effectiveness. The program manual can be distributed to the teachers working in disadvantageous regions and their in-service training activities can be planned for the purpose of preventing the social-emotional incompetence of the children. Applied courses on methods for coping with the behavioral problems should be provided to the candidate teachers at universities. It is also suggested to provide in-service trainings for developing social and emotional competence to teachers, to provide families with seminars on how they would support social and emotional competence of children, to perform regularly family involvement activities for improving social and emotional competence, to develop measurement tools for determining social and emotional competence of preschool children, to conduct studies on this subject, and to identify which variables are able to affect social and emotional competence of young children.

\section{References}

Alp, H. (2016). Okul öncesi dönemdeki çocukların saldırgan davranışları ve sosyalleşme süreçlerine akran eğitimi ve oyun etkinliklerinin etkisi. International Journal of Social Sciences and Education Research, 2(2):788-813.

Aslan, E. (2008). Drama temelli sosyal beceri eğitiminin 6 yaş çocuklarının sosyal ilişkiler ve işbirliği davranışlarına etkisi. Yayımlanmamış yüksek lisans tezi. Aydın: Adnan Menderes Üniversitesi

Avcıoğlu, H. (2007). Sosyal becerileri değerlendirme ölçeğinin geçerlilik güvenilirlik çalışması (4-6 yaş). Abant Izzet Baysal Eğitim Fakültesi Dergisi, 7(2): 93-103.

Brauner, C. B., \& Stephens, C. B. (2006). Estimating the prevalence of early childhood serious emotional/behavioral disorders: Challenges and recommendations. Public Health Reports, 121(3): 303-310.

Büyüköztürk, S. (2007). Sosyal bilimler için veri analizi el kitabı (8. Baskı). Ankara: PegemA Yayıncılık.

Clay, C. D. (1995). A qualitative study of the social competence of at-risk native American children during their transition from an Indian Head Start Program to a public school kindergarten. Unpublished doctoral dissertation. USA: University of Denver.

Domitrovich, C. E., Cortes, R. C., \& Greenberg, M. T. (2007). Improving young children's social and emotional competence: A randomized trial of the preschool "PATHS" curriculum. The Journal of Primary Prevention, 28(2), 67-91. 
Eccles, J. S., \& Harold, D. H. (1993). Parent-school involvement during the early adolescent years. Teachers College Record, 94: 568-87.

Ekiz, D. (2003). Eğitimde araştırma yöntem ve metotlarına giriş: Nitel, nicel ve eleştirel kuram metodolojileri. Ankara: Anı Yayıncılık.

Elias, M. J., Parker, S. J., Kash, V. M., Weissberg, R. P., \& O'Brien, M. U. (2008). Social and emotional learning, moral education, and character education. In L. Nucci \& D. Narvaez (Eds.), Handbook of moral education (pp.1017-1032). Mahwah, NJ: Lawrence Erlbaum Associates.

Ekinci-Vural, D. (2006). Okul öncesi eğitim programındaki duyuşsal ve sosyal becerilere yönelik hedeflere uygun olarak hazırlanan aile katılımlı sosyal beceri eğitim programının çocuklarda sosyal becerilerin gelişimine etkisi. Yayımlanmamış yüksek lisans tezi, İzmir: Dokuz Eylül Üniversitesi.

Grace, R., Boews, J., \& Elcombe, E. (2014). Child participation and family engagement with early childhood education and care services in disadvantaged Australian communities. International Journal of Early Childhood. 46: 271-298.

Gülay Ogelman, H. (2017). Okul öncesi dönemde akran ilişkileri (3. baskı). Ankara: Eğiten Kitap.

Göktaş, ì. (2015). Aile katılımı ve sosyal beceri eğitimi programlarının tek başına ve birlikte 4-5 yaş çocuklarının sosyal becerileri ve anne-çocuk ilişkileri üzerindeki etkisinin incelenmesi. Yayımlanmamış yüksek lisans tezi, Denizli: Pamukkale Üniversitesi.

Hemmeter, M. L., Santos, R. M., \& Ostrosky, M. M. (2008). Preparing early childhood educators to address young children's social-emotional development and challenging behavior: A survey of higher education programs in nine states. Journal of Early Intervention, 30(4): 321-340.

Kam, C., Greenberg, M. T., \& Kusché, C. A. (2004). Sustained effects of the PATHS curriculum on the social and psychological adjustment of children in special education. Journal of Emotional and Behavioral Disorders, 12 (2): 66-78.

Kandır, A. ve Alpan, Y. (2008). Okul öncesi dönemde sosyal-duygusal gelişime anne-baba davranışlarının etkisi. Aile ve Toplum, 4(14): 33-38.

Karasar, N. (2006). Bilimsel araştırma yöntemi: Kavramlar, ilkeler, teknikler (16.baskı). Ankara: Nobel Yayınları.

Kramer, T., J., Caldarella, P., Christensen, L., \& Shatzer, R. H. (2010). Social-emotional learning in kindergarten classrooms: Evaluation of the Strong Start curriculum. Early Childhood Education Journal, 37 (4): 33-39.

Merrell, K. W. (1996). Social-emotional problems in early childhood: New directions in conceptualization, assessment, and treatment. Education and Treatment of Children, 19(4): 458-473.

Önder, A., Dağal, A. B. ve Şallı, D. (2015). 5-6 yaş çocukları için iletişim becerileri ölçeği geçerlik-güvenirlik çalışması. Eğitim ve Öğretim Araştırmaları Dergisi, 1(4): 1-13.

Özdemir-Topaloğlu, A. (2013). Etkinlik Temelli Sosyal Beceri Eğitimi’nin çocukların akran ilişkilerine etkisi, Yayımlanmamış doktora tezi, Konya: Selçuk Üniversitesi.

Pahl, K. M., \& Barrett, P. M. (2007). The development of social-emotional competence in preschool-aged children: An introduction to the Fun FRIENDS program. Australian Journal of Guidance \& Counselling, 17(1): 81-90. 
Polat, Ö. ve Dilli, F. (2015). 60-72 Aylık sosyal açıdan dezavantajlı çocuklar için hazırlanan destek programının çocukların ilkokula hazırbulunuşluğuna etkisi. Uluslararası Eğitim Programları ve Öğretim Çalışmaları Dergisi, 5(9): 81-103.

Ramazan, O., \& Ünsal, Ö. (2012). A study on the relationship between the social-emotional adaptation and behavioral problems of 60-72 month old preschoolers. Procedia - Social and Behavioral Sciences, 46: 5828-5832.

Saltalı, N. D. (2013). Okul öncesi dönemde duygusal becerilerin geliştirilmesi. Yalova Sosyal Bilimler Dergisi, 3(6): 107-119.

Sayın, U. (2014). 48-72 Aylık çocuklardaki saldırganlık davranışlarına müdahale yöntemi olarak ebeveyn eğitim programı geliştirilmesi ve etkililiğinin incelenmesi. Yayımlanmamış doktora tezi, Ankara: Hacettepe Üniversitesi.

Schmidt, M. E., Demulder, E. K., \& Denham, S. A. (2002). Kindergarten social-emotional competence: Developmental predictors and psychosocial implications. Early Child Development and Care, 172: 451-462.

Stefan, C. A. (2012). Social-emotional prevention program for preschool children: An analysis of a high risk sample. Cognition, Brain, Behavior: An Interdisciplinary Journal, 16(3): 319-356.

Tremblay, R. E., Pagani-Kurtz, L., Mâsse, L. C., Vitaro, F. ve Pihl, R. O. (1995). A bimodal preventive intervention for disruptive kindergarten boys: Its impact through mid-adolescence. Journal of Consulting and Clinical Psychology, 63(4): 560-568.

Tulunanda, O. (1999). Mothers' and fathers' interaction with preschoolers in the home in Northern Thailand: relationships to teachers' assessments of children social skills. Unpublished doctoral dissertation. USA: Syracause University.

Uysal, A. ve Kaya Balkan, İ. (2015). Sosyal beceri eğitimi alan ve almayan okul öncesi çocukların, sosyal beceri ve benlik kavramı düzeyleri açısından karşılaştırılması. Psikoloji Çalışmaları Dergisi, 35(1): 2756.

Webster-Stratton, C., \& Hammond, M. (1997). Treating children with early-onset problems: A comparison of child and parent training interventions. Journal of Consulting and Clinical Psychology, 65(1): 93109.

Webster-Stratton, C., \& Reid, M. J. (2004). Strengthening social and emotional competence in young children-The foundation for early school readiness and success Incredible Years Classroom Social Skills and Problem-Solving Curriculum. Infants and Young Children, 17(2): 96-113.

Yalçın, H. (2013). Anne-çocuk iletişimi eğitiminin etkileri. Süleyman Demirel Üniversitesi Sosyal Bilimler Dergisi, 28: 179-194.

Yıldırım, A. ve Şimşek, H. (2006). Sosyal bilimlerde nitel araştırma yöntemleri. (5. Baskı). Ankara: Seçkin Yayınları.

Yumuş, M. (2013). Okul öncesi eğitimcilerin 36-72 ay aralığındaki çocukların davranış problemleri ile ilgili görüşlerinin incelenmesi ve başa çıkma stratejilerinin belirlenmesi. Yayımlanmamış yüksek lisans tezi. Ankara: Hacettepe Üniversitesi. 